\title{
Award-winning paper in 2017
}

Papers published in Engineering History and Heritage are eligible for awards from the Institution of Civil Engineers. Papers from any of the ICE journals can be nominated for several awards. In addition, each journal has awards dedicated to their specific subject area.

On Monday 8 October 2018, ICE president Robert Mair presented awards to the following papers published in Engineering History and Heritage in 2017. The Editorial Panel nominated their best papers and an awards committee chaired by Nigel Wright allocated the awards.

\section{Thomas Telford Premium Prize}

The Thomas Telford Premium Prize, presented for the best paper published in Engineering History and Heritage, was awarded to Fernandez (2017).

\begin{abstract}
This paper discusses some of the considerations that engineers may need to take when assessing and working on historic buildings or assets. It outlines the philosophy of conservation and draws on experience gained using case studies of projects that the author has worked on for illustration. It highlights not only that an engineer needs to develop a wide array of skills and knowledge in order to carry out any works on historic structures, but also that an engineer can have a pivotal role in helping to protect and prolong the life of cultural heritage.
\end{abstract}

\section{Mokshagundam Visvesvaraya Prize}

The Mokshagundam Visvesvaraya Prize, presented to the best two papers received on a subject connected with works carried out outside the British Isles, was awarded to Gallegos Mayorga et al. (2017).

\begin{abstract}
Numerous wrought-iron bridges can be found in the French railway network. Since most of this architectural heritage was built during the second half of the nineteenth century, these old riveted structures have been in service for over 100 years and need an adapted maintenance policy. This paper, done in collaboration between the University of Brest (France) and the National Society of French Railways, presents the French railway network, its wroughtiron riveted bridges and the different scales used to analyse their mechanical behaviour. Once these are established, the paper presents an experimental strategy carried out to identify the behaviour of a riveted constructional detail under quasi-static and cyclic loadings through the manufacture and testing of double-shear hot-riveted specimens. The tested assemblies were fabricated from the recovered material from the demolished bridge over Adour River (France). The tests showed an important scatter on the mechanical behaviour of the riveted wrought-iron specimens (for both tensile and fatigue tests). This was mainly attributed to material and process parameters. A static loading scenario was proposed, and the fatigue tests were statistically analysed and the results compared to data found in the literature.
\end{abstract}

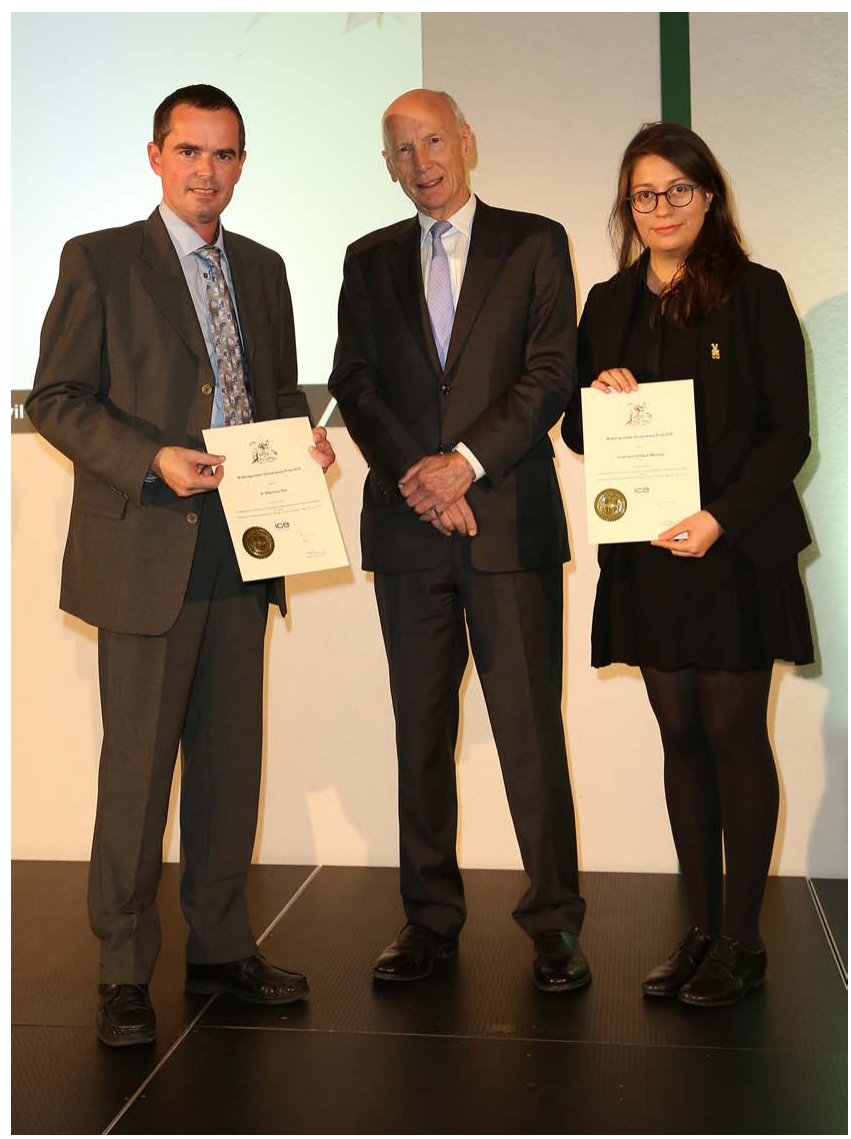

Figure 1. Mokshagundam Visvesvaraya Prize winners Stéphane Sire (left) and Linamaria Gallegos Mayorga (right) with ICE President Robert Mair

\section{REFERENCES}

Fernandez S (2017) Engineer's approach to conservation. Proceedings of the Institution of Civil Engineers - Engineering History and Heritage 170(2): 53-66, https://doi.org/10.1680/jenhh.16.00018.

Gallegos Mayorga L, Sire S, Ragueneau M and Plu B (2017) Understanding the behaviour of wrought-iron riveted assemblies: manufacture and testing in France. Proceedings of the Institution of Civil Engineers - Engineering History and Heritage 170(2): 67-79, https://doi.org/10.1680/jenhh.16.00020. 